\title{
Alkynylcarbyne complexes containing various tri- and bidentate ligands such as cyclopentadienide, tris(pyrazolyl)borate, bis(pyrazolyl)acetate and tmeda: synthesis and spectroscopic properties
}

\author{
Birgit Schwenzer, Joachim Schleu, Nicolai Burzlaff, Christoph Karl, Helmut Fischer* \\ Fachbereich Chemie, Universität Konstanz, Fach M727, D-78457 Konstanz, Germany
}

Received 4 July 2001; accepted 7 August 2001

\begin{abstract}
A bstract
The (alkynylcarbyne)tungsten complexes $\left[\mathrm{L}_{3}(\mathrm{CO})_{2} \mathrm{~W} \equiv \mathrm{C}-\mathrm{C} \equiv \mathrm{C}-\mathrm{R}\right](\mathbf{3} \mathbf{a}, \mathbf{b}-\mathbf{6 a}, \mathbf{b})\left[\mathrm{L}_{3}=\right.$ hydro[tris $(3,5$-dimethylpyrazol-1-yl)]borato ( $\left.\mathrm{Tp}^{\prime}, 3\right)$, hydro[tris(pyrazol-1-yl)]borato (Tp, 4), cyclopentadienyl (Cp, 5), bis(3,5-dimethylpyrazol-1-yl)acetato (bdmpza, 6); $\left.\mathrm{R}=\mathrm{SiMe}_{3}(\mathbf{a}), \mathrm{Ph}(\mathbf{b})\right]$ were prepared in a stepwise fashion from $\left[\mathrm{W}(\mathrm{CO})_{6}\right]$ and $\mathrm{Li}[\mathrm{C} \equiv \mathrm{CR}],\left(\mathrm{CF}_{3} \mathrm{CO}\right)_{2} \mathrm{O}$ and $\mathrm{M}\left[\mathrm{L}_{3}\right](\mathrm{M}=\mathrm{Na}, \mathrm{K})$. The formation of $\mathbf{6 a}, \mathbf{b}$ was highly selective, only complexes with a trans arrangement of the carboxylate group of bdmpza and the alkynylcarbyne ligand were detected. The reaction of $\left[\mathrm{W}(\mathrm{CO})_{6}\right]$ with $\mathrm{Li}[\mathrm{C} \equiv \mathrm{CR}], \mathrm{C}_{2} \mathrm{O}_{2} \mathrm{Cl}_{2}$ and tmeda afforded trans$\left[\mathrm{Cl}(\mathrm{CO})_{2}(\mathrm{tmeda}) \mathrm{W} \equiv \mathrm{C}-\mathrm{C} \equiv \mathrm{C}-\mathrm{R}\right](\mathbf{7 a}, \mathbf{b})$. The electron-donating potential of the different tripodal ligands $\mathrm{L}_{3}$ was studied by IR-and ${ }^{13} \mathrm{C}$-NMR spectroscopy and compared to that of the ligand combination $\mathrm{Cl} / \mathrm{tmeda}$. The IR data suggest that in these complexes bdmpza is a weaker electron donor than $\mathrm{Tp}^{\prime}$ and $\mathrm{Tp}$ but displays stronger electron-donating abilities than $\mathrm{Cp}$. The structures of 6b and 7b were established by X-ray structural analyses. (C) 2002 Elsevier Science B.V. All rights reserved.
\end{abstract}

Keywords: Carbyne complexes; Tripodal ligands; Tungsten; Electron donating ability

\section{Introduction}

Organometallic compounds with extended $\pi$-conjugated ligands have attracted considerable interest [1], since bi- and polynuclear complexes containing $\pi$-unsaturated conjugated bridges are expected to exhibit potentially useful physical and chemical properties. In such bi- and polynuclear complexes the metal-ligand fragment $\mathrm{L}_{n} \mathrm{M}$ can occupy an internal or/and a terminating position in the chain. Various types of bridging ligands have been proposed. In recent years attention has focused on complexes with carbon-rich bridges, $\left[\operatorname{LnM}(\mathrm{C})_{m} \mathrm{M}^{\prime} \mathrm{L}_{n}^{\prime}\right]$ [2]. Until now, complexes with an even number of carbon atoms linking the metals ( $m$ up to 20 [3]) are more readily accessible than those with an odd number of carbon atoms. Usually, complexes with

\footnotetext{
* Corresponding author. Tel.: + 49-7531-882783; fax: + 49-7531883136.

E-mail address: helmut.fischer@uni-konstanz.de (H. Fischer).
}

an even number of carbon atoms are derived from alkynes and alkynyl complexes via coupling reactions. In contrast, precursors for the synthesis of complexes with an odd number of bridging carbon atoms are much less readily available.

Alkynylcarbyne complexes (alkynylidyne complexes), $\mathrm{L}_{n} \mathrm{M} \equiv \mathrm{C}-(\mathrm{C} \equiv \mathrm{C})_{m}-\mathrm{R}$, might be suitable starting compounds for the synthesis of complexes with an odd number of bridging carbon atoms. In addition, they also might constitute interesting terminating groups. However, until now there are only a few reports on alkynylcarbyne complexes. The first complexes, trans$\mathrm{X}(\mathrm{CO})_{4} \mathrm{~W} \equiv \mathrm{C}-\mathrm{C} \equiv \mathrm{C}-\mathrm{Ph}(\mathrm{X}=\mathrm{Cl}, \mathrm{Br}, \mathrm{I})$, were prepared by Fischer et al. already in 1974 [4]. Since then, only a few more alkynylcarbyne complexes containing bi- and tridentate ligands, $\mathrm{L}_{n} \mathrm{M} \equiv \mathrm{C}-\mathrm{C} \equiv \mathrm{C}^{n} \mathrm{Bu}(\mathrm{M}=\mathrm{Mo}, \mathrm{W})$, have been reported by Stone and coworkers [5].

We now report on the synthesis and the spectroscopic properties of a series of alkynylcarbyne complexes of tungsten containing tripodal ligands, 


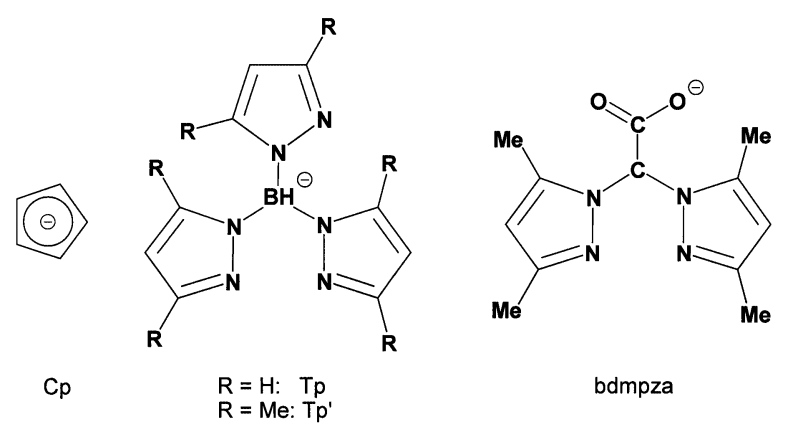

Scheme 1.
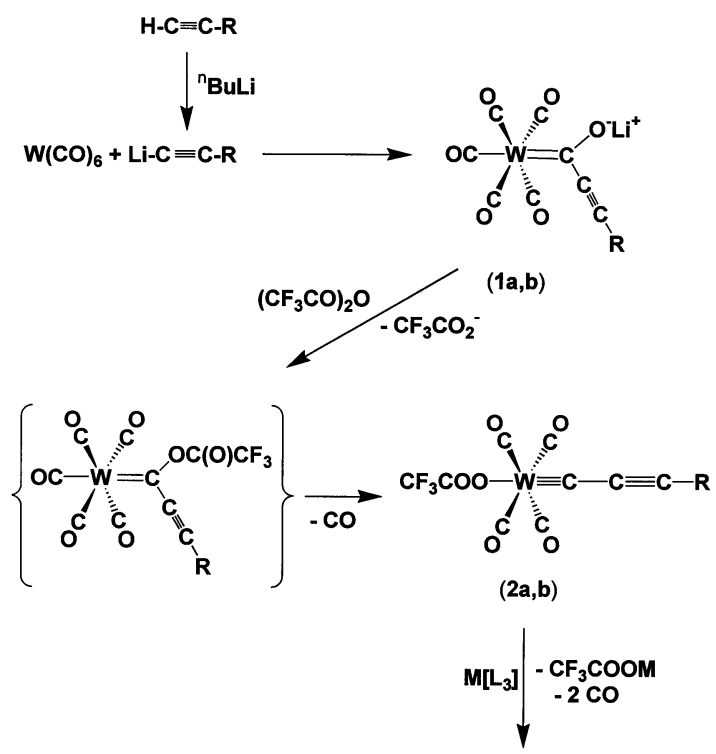

$\mathrm{R}=\mathrm{SiMe}_{3}(\mathbf{a}), \mathrm{Ph}(\mathbf{b})$

$L_{3}=T p^{\prime}(3), T p(4), C p(5)$, bdmpza (6)

$\mathrm{M}=\mathrm{Na}, \mathrm{K}$

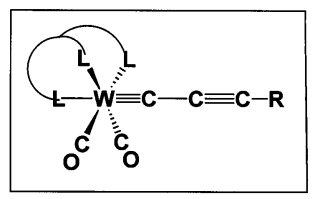

$(3 a, b-6 a, b)$

Scheme 2.

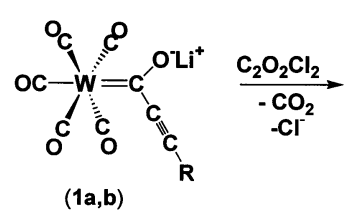

$(\mathbf{1 a}, \mathbf{b})$

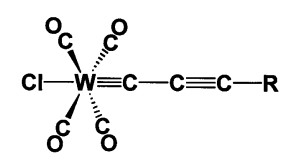

$\mathrm{R}=\mathrm{SiMe}_{3}(\mathbf{a}), \mathrm{Ph}(\mathbf{b})$

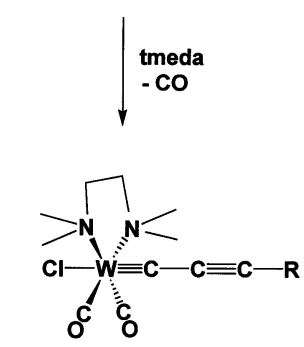

$(7 a, b)$
$\mathrm{L}_{3}(\mathrm{CO})_{2} \mathrm{~W} \equiv \mathrm{C}-\mathrm{C} \equiv \mathrm{CR}$, as well as of two tmeda complexes. To have a rather broad range of electronic properties available, in addition to cyclopentadienide (Cp), hydro[tris(pyrazol-1-yl)]borate (Tp), hydro[tris(3,5-dimethylpyrazol-1-yl)]borate ( $\left.\mathrm{Tp}^{\prime}\right)$ [6] and the new scorpionate ligand bis(3,5-dimethylpyrazol-1yl)acetate (bdmpza) recently reported by Otero et al. [7] and Burzlaff and coworkers [8] were used as coligands (Scheme 1). The alkynylcarbyne substituent $\mathrm{R}\left(\mathrm{SiMe}_{3}\right.$, $\mathrm{Ph}$ ) was chosen in such a way as to be able to further functionalize the complexes and use them as precursors for the synthesis of bi- and polynuclear complexes.

\section{Results and discussion}

Fischer-type carbyne complexes are usually prepared by either one of the two following pathways:

(a) transformation of carbene into carbyne complexes by reaction with trihalides of Group III elements (B [9], $\mathrm{Al}$ [10], Ga [11]) or

(b) abstraction of an oxide, $\mathrm{O}^{2-}$, from an acyl metallate by e.g. $\mathrm{Ph}_{3} \mathrm{PBr}_{2}$ [12], $\mathrm{SOCl}_{2}$ [13], $\mathrm{COCl}_{2}$, oxalyl halides, or $\left(\mathrm{CF}_{3} \mathrm{CO}\right)_{2} \mathrm{O}[14]$.

For the synthesis of alkynylcarbyne complexes pathway (b) turned out to be more efficient than pathway (a) affording higher yields. Addition of $\mathrm{Li}[\mathrm{C} \equiv \mathrm{C}-\mathrm{R}]$ to $\left[\mathrm{W}(\mathrm{CO})_{6}\right]$ in THF or $\mathrm{Et}_{2} \mathrm{O}$ gave the acyl tungstates $\mathbf{l a}, \mathbf{b}$ $[15,16]$. Subsequent oxide abstraction with trifluoracetic anhydride at $-80{ }^{\circ} \mathrm{C}$ [14] afforded the trans-tetracarbonyl(trifluoracetato)tungsten complexes $\mathbf{2} \mathbf{a}, \mathbf{b}$. The trifluoracetato ligand is only weakly coordinated and, therefore, is easily replaced by other anions. The tetracarbonyl complexes $\mathbf{2} \mathbf{a}, \mathbf{b}$ were not isolated but immediately transformed at $-50{ }^{\circ} \mathrm{C}$ into the complexes $\mathbf{3} \mathbf{a}, \mathbf{b}-\mathbf{6} \mathbf{a}, \mathbf{b}$ (Scheme 2) by reaction with the sodium or potassium salts of the tripodal ligand $\left(\mathrm{NaTp}^{\prime}, \mathrm{KTp}\right.$, $\mathrm{NaCp}$ or K[bdmpza]). The reaction was accompanied by $\mathrm{CO}$ evolution. Column chromatography of the crude products of $\mathbf{3} \mathbf{a}, \mathbf{b}-\mathbf{5} \mathbf{a}, \mathbf{b}$ finally afforded the pure complexes in moderate yield (14-56\% overall yield, three steps). Deviating from this purification procedure complexes $\mathbf{6 a}, \mathbf{b}$ were obtained in 83 and $91 \%$ yield by precipitation from the reaction mixture (addition of pentane to solutions in diethyl ether) and subsequent recrystallization.

All complexes are poorly soluble in unpolar organic solvents but readily soluble in polar solvents. In the solid state, all compounds are stable at room temperature. At $-30{ }^{\circ} \mathrm{C}$, they can be stored under inert gas for prolonged periods without noticeable decomposition. In solution at room temperature, however, complexes $\mathbf{3 a}, \mathbf{b}-\mathbf{5 a}, \mathbf{b}$ slowly decompose.

For comparison, additionally the alkynylcarbyne complexes $\mathbf{7 a , b}$ containing a bidentate ligand (tmeda) were synthesized from $\left[\mathrm{W}(\mathrm{CO})_{6}\right]$ and $\mathrm{Li}[\mathrm{C} \equiv \mathrm{CR}](\mathrm{R}=$ 


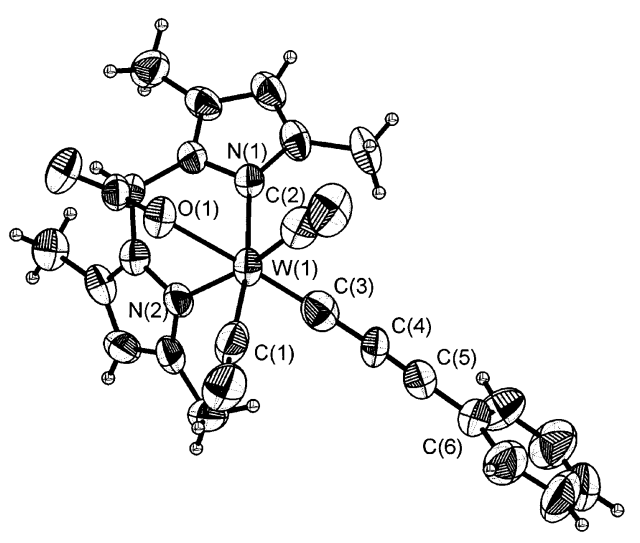

Fig. 1. Molecular structure of complex $\mathbf{6 b}$ in the crystal (solvent molecule omitted for clarity).

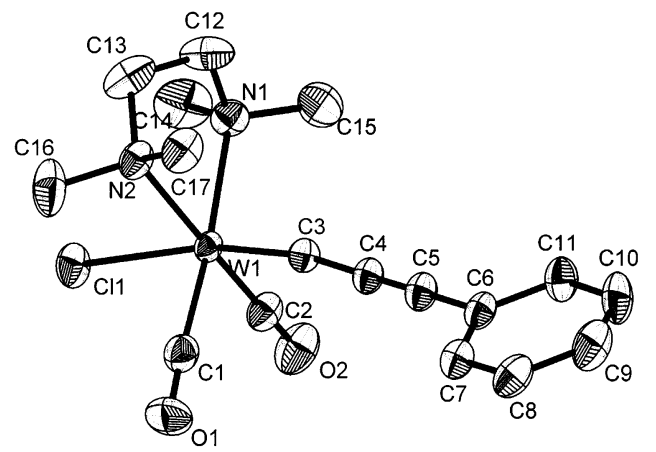

Fig. 2. Molecular structure of complex $\mathbf{7 b}$ in the crystal (hydrogen atoms and solvent molecule are omitted for clarity).

Table 1

Selected bond distances and angles in $\mathbf{6} \mathbf{b}$ and $\mathbf{7 b}$

\begin{tabular}{lcc}
\hline & $6 \mathbf{b}$ & $\mathbf{7 b}$ \\
\hline Bond lengths & & \\
$\mathrm{W}(1)-\mathrm{C}(1)$ & $2.032(14)$ & $1.986(6)$ \\
$\mathrm{W}(1)-\mathrm{C}(2)$ & $2.024(13)$ & $1.983(5)$ \\
$\mathrm{W}(1)-\mathrm{C}(3)$ & $1.839(13)$ & $1.834(5)$ \\
$\mathrm{W}(1)-\mathrm{N}(1)$ & $2.247(8)$ & $2.304(4)$ \\
$\mathrm{W}(1)-\mathrm{N}(2)$ & $2.233(9)$ & $2.300(4)$ \\
$\mathrm{W}(1)-\mathrm{O}(3)$ & $2.222(7)$ & \\
$\mathrm{W}(1)-\mathrm{Cl}(1)$ & & $2.5098(14)$ \\
$\mathrm{C}(3)-\mathrm{C}(4)$ & $1.429(16)$ & $1.376(6)$ \\
$\mathrm{C}(4)-\mathrm{C}(5)$ & $1.216(15)$ & $1.204(7)$ \\
$\mathrm{C}(5)-\mathrm{C}(6)$ & $1.457(15)$ & $1.427(6)$ \\
Bond angles & & \\
$\mathrm{C}(3)-\mathrm{W}(1)-\mathrm{C}(1)$ & $88.6(5)$ & $82.4(2)$ \\
$\mathrm{C}(3)-\mathrm{W}(1)-\mathrm{C}(2)$ & $85.1(5)$ & $100.16(19)$ \\
$\mathrm{C}(3)-\mathrm{W}(1)-\mathrm{N}(1)$ & $99.7(4)$ & $97.27(17)$ \\
$\mathrm{C}(3)-\mathrm{W}(1)-\mathrm{N}(2)$ & $102.8(4)$ & $168.4(4)$ \\
$\mathrm{W}(1)-\mathrm{C}(3)-\mathrm{C}(4)$ & $178.1(10)$ & $175.7(5)$ \\
$\mathrm{C}(3)-\mathrm{C}(4)-\mathrm{C}(5)$ & $177.3(12)$ & $176.9(5)$ \\
$\mathrm{C}(4)-\mathrm{C}(5)-\mathrm{C}(6)$ & $179.2(12)$ & \\
\hline
\end{tabular}

$\mathrm{SiMe}_{3}, \mathrm{Ph}$ ), oxalyl chloride and tmeda (Scheme 3). After chromatography, $7 \mathrm{a}$ was obtained in $22 \%, 7 \mathrm{~b}$ in $24 \%$ overall yield. Compounds $\mathbf{7 a}, \mathbf{b}$ are less stable than 3a,b-6a,b. Nevertheless, they can be heated to at least $80{ }^{\circ} \mathrm{C}$ but start to decompose quickly above ca. $120{ }^{\circ} \mathrm{C}$.

The metal in these complexes $\mathbf{3} \mathbf{a}, \mathbf{b}-\mathbf{6} \mathbf{a}, \mathbf{b}$ and $\mathbf{7 a}, \mathbf{b}$ is pseudo-octahedrally coordinated, the tripodal ligand in $\mathbf{3 a}, \mathbf{b}-\mathbf{6} \mathbf{a}, \mathbf{b}$ occupying a facial position. In contrast to $\mathbf{3} \mathbf{a}, \mathbf{b}-\mathbf{5} \mathbf{a}, \mathbf{b}$, two isomers are conceivable for complexes $6 \mathbf{a}$ and $\mathbf{6 b}$ : there is either a trans arrangement of a 3,5-dimethylpyrazolyl group and the alkynylcarbyne ligand (isomer $\mathbf{A}$ ) or of the carboxylate and the alkynylcarbyne ligand (isomer B). IR, ${ }^{1} \mathrm{H}$ - and ${ }^{13} \mathrm{C}-\mathrm{NMR}$ spectra indicate that a single isomer is formed. The ${ }^{1} \mathrm{H}-\mathrm{NMR}$ spectra of $\mathbf{6 a}$ and $\mathbf{6} \mathbf{b}$ exhibit a single set of resonances for the pyrazolyl groups (e.g. two $\mathrm{Me}$ peaks). In contrast, for $\mathbf{3} \mathbf{a}$ and $\mathbf{3} \mathbf{b}$ four $N$-methyl resonances are observed. The ${ }^{13} \mathrm{C}$-NMR spectra show only one peak for the two $\mathrm{CO}$ ligands at a position $[\delta=$ 225.9 (6a) and $226.0 \mathrm{ppm}(\mathbf{6 b})]$ similar to that of the $\mathrm{CO}$ resonances in $\mathbf{3} \mathbf{a}, \mathbf{b}$ and $\mathbf{4 a} \mathbf{a}, \mathbf{b}(\delta=226.1-227.3 \mathrm{ppm})$. From these observation it follows that in solution isomer B is present. The conclusion is supported by the results of the X-ray analysis of complex $\mathbf{6 b}$. Until now, there is no solid-state structure of a complex with a terminally bonded alkynylcarbyne ligand available. Only a complex featuring a bridging $\mathrm{C}-\mathrm{C} \equiv \mathrm{C}-\mathrm{CMe}_{3}$ ligand [17] and a binuclear $\mathrm{Re}-\mathrm{W}$ complex with a nearly linear $\mathrm{C}_{3}$ bridge, $\left[\mathrm{Cp} *\left(\mathrm{PPh}_{3}\right)(\mathrm{NO}) \mathrm{Re}-\right.$ $\left.\mathrm{C} \equiv \mathrm{C}-\mathrm{C} \equiv \mathrm{W}\left(\mathrm{O}^{t} \mathrm{Bu}\right)_{3}\right](\mathbf{8})[18]$, have been characterized by $\mathrm{X}$-ray structural analyses. Therefore, the structure of $\mathbf{7 b}$ was also established by an X-ray analysis.

In both complexes, 6b (Fig. 1) and 7b (Fig. 2), the coordination octahedron is slightly distorted. The $\mathrm{CO}$ ligands are bent towards the alkynylcarbyne ligand. Conversely, the $\mathrm{C}$ (carbyne) $-\mathrm{W}-\mathrm{N}$ angle is $>90^{\circ}$. As has already been deduced from the NMR spectra the carboxylate in $\mathbf{6 b}$ occupies the position trans to the alkynylcarbyne ligand. The $\mathrm{W} \equiv \mathrm{C}$ (carbyne) distance is equal in both compounds [1.839(13) $\AA$ in 6 b , 1.834(5) $\AA$ in 7b] (Table 1) and compares well with that in the tolylcarbyne complex $\quad\left[\mathrm{Tp}^{\prime}(\mathrm{CO})_{2} \mathrm{~W} \equiv \mathrm{C}-\mathrm{C}_{6} \mathrm{H}_{4} \mathrm{Me}-p\right]$ $\left((1.829(3) \AA)\right.$ [19]. Obviously, the trans ligand $\left(\mathrm{RCOO}^{-}\right.$ , $\mathrm{Cl}^{-}$, pyrazolyl) does not significantly influence the $\mathrm{W} \equiv \mathrm{C}$ (carbyne) bond length. However, the $\left({ }^{t} \mathrm{BuO}\right)_{3} \mathrm{~W} \equiv \mathrm{C}$ distance in 8 is significantly shorter $(1.769(8) \AA)$ [18]. Due to the $\pi$-acceptor properties of the pyrazolyl ligands in $\mathbf{6 b}$ the $\mathbf{W}-\mathrm{CO}$ distances in $\mathbf{6 b}$ is longer than in 7b (2.024-2.032(14) $\AA$ in 6b, 1.983-1.986(6) $\AA$ in 7b). The $\mathrm{C}(3)-\mathrm{C}(4)$ distance in $\mathbf{6 b}(1.429(16) \AA)$ and $\mathbf{7 b}$ (1.376(6) A) compares well with the median value for a $\mathrm{C}(\mathrm{sp})-\mathrm{C}(\mathrm{sp})$ single bond $(1.377 \AA[20])$. The $\mathrm{C}(4)-\mathrm{C}(5)$ distance $(1.216(15) \AA$ in $6 \mathbf{b}$ and $1.204(7) \AA$ for $7 \mathbf{b})$ is also in the range usually observed for $\mathrm{C} \equiv \mathrm{C}$ bonds $(1.183$ $\AA$ [20]). Whereas the WCCC fragment in $\mathbf{6 a}$ is nearly linear $\left(\mathrm{W}-\mathrm{C}-\mathrm{C} 178.1(10)^{\circ}, \mathrm{C}-\mathrm{C}-\mathrm{C} 177.3(12)^{\circ}\right)$, that in $7 \mathrm{~b}$ is slightly bent (W-C(3)-C(4) 168.4(4) ${ }^{\circ}$, 
$\left.\mathrm{C}(3)-\mathrm{C}(4)-\mathrm{C}(5) 175.7(5)^{\circ}\right)$. The deviation from linearity is presumably due to packing effects in the crystal.

All alkynylcarbyne complexes display two $v(\mathrm{CO})$ absorptions of similar intensity as expected for cis$\left[\mathrm{L}_{4} \mathrm{M}(\mathrm{CO})_{2}\right]$ complexes. An additional weak absorption at $2050-2057 \mathrm{~cm}^{-1}$ in the spectra of the trimethylsilylethynylcarbyne complexes $\mathbf{3} \mathbf{a}-\mathbf{7} \mathbf{a}$ is assigned to the $v(\mathrm{C} \equiv \mathrm{C})$ vibration. The corresponding absorption of the phenylethynylcarbyne complexes is at about $50 \mathrm{~cm}^{-1}$ higher wavenumbers indicating stronger $\pi$-acceptor properties of $\mathrm{C}-\mathrm{C} \equiv \mathrm{C}-\mathrm{SiMe}_{3}$ compared to $\mathrm{C}-\mathrm{C} \equiv \mathrm{C}-\mathrm{Ph}$. The conclusion agrees with the observation that the $v(\mathrm{CO})$ absorptions of the phenylethynylcarbyne complexes $\mathbf{3} \mathbf{b}-\mathbf{7} \mathbf{b}$ are at slightly smaller wavenumbers than those of $3 \mathbf{a}-\mathbf{7 a}$.

From the shift in the $v(\mathrm{CO})$ absorptions (Table 1) we can deduce a decrease in the electron donating ability in the order $\mathrm{Tp}^{\prime}>\mathrm{Tp}>\mathrm{Cp}$. The same order has been reported before by Stone and coworkers [5] for $t$ butylethinylcarbyne complexes of molybdenum. A higher electron-donating potential of $\mathrm{Tp}$ compared to $\mathrm{Cp}$ has also been observed by McElwee-White and coworkers [21] with some molybdenum carbyne complexes.

Replacement of one strongly $\sigma$-donating pyrazolyl group in $\mathrm{Tp}$ by the electronegative $\mathrm{C}(=\mathrm{O}) \mathrm{O}^{-}$group $(\mathbf{4} \rightarrow \mathbf{6})$ should reduce the electron-donating properties of the tripodal ligand, although the effect should be less pronounced for a substitution cis to $\mathrm{CO}$ than trans to $\mathrm{CO}$. The assumption is confirmed by the $v(\mathrm{CO})$ absorptions: the influence of the new bdmpza tripodal ligand on the carbonyl vibrations is intermediate between that of $\mathrm{Tp}$ and $\mathrm{Cp}$. Thus, with respect to the electronic influence of various tripodal ligands on the metal bdmpza fills in the gap between Tp and Cp. Based on the $v(\mathrm{CO})$ spectra the $\sigma$-donor $/ \pi$-acceptor ratio of the tripodal bdmpza ligand is comparable to the ligand combination tmeda $/ \mathrm{Cl}^{-}$.

Table 2

$v(\mathrm{CO})$ and $v(\mathrm{C} \equiv \mathrm{C})$ absorptions of the complexes $\mathbf{3} \mathbf{a}, \mathbf{b}-\mathbf{7} \mathbf{a}, \mathbf{b}\left(\right.$ in $\left.^{\mathrm{cm}}{ }^{-1}\right)$ in THF

\begin{tabular}{|c|c|c|c|}
\hline Complex & $\mathrm{A}_{1}$ & $\mathrm{~B}_{1}$ & $v(\mathrm{C} \equiv \mathrm{C})$ \\
\hline$\left[\mathrm{Tp}^{\prime}(\mathrm{CO})_{2} \mathrm{~W} \equiv \mathrm{C}-\mathrm{C} \equiv \mathrm{C}-\mathrm{SiMe}_{3}\right](\mathbf{3 a})$ & 1982 & 1896 & 2052 \\
\hline$\left[\mathrm{Tp}(\mathrm{CO})_{2} \mathrm{~W} \equiv \mathrm{C}-\mathrm{C} \equiv \mathrm{C}-\mathrm{SiMe}_{3}\right](\mathbf{4 a})$ & 1991 & 1906 & 2056 \\
\hline$\left[\mathrm{Cp}(\mathrm{CO})_{2} \mathrm{~W} \equiv \mathrm{C}-\mathrm{C} \equiv \mathrm{C}-\mathrm{SiMe}_{3}\right](\mathbf{5 a})$ & 1995 & 1923 & 2057 \\
\hline $\begin{array}{l}{\left[(\text { bdmpza })(\mathrm{CO})_{2} \mathrm{~W} \equiv \mathrm{C}-\mathrm{C} \equiv \mathrm{C}-\mathrm{SiMe}_{3}\right]} \\
\quad(6 \mathrm{a})\end{array}$ & 1995 & 1912 & 2052 \\
\hline $\begin{array}{l}{\left[\mathrm{Cl}(\text { tmeda })(\mathrm{CO})_{2} \mathrm{~W} \equiv \mathrm{C}-\mathrm{C} \equiv \mathrm{C}-\mathrm{SiMe}_{3}\right]} \\
\quad(\mathbf{7 a})^{\mathrm{a}}\end{array}$ & 1997 & 1908 & 2050 \\
\hline$\left[\mathrm{Tp}^{\prime}(\mathrm{CO})_{2} \mathrm{~W} \equiv \mathrm{C}-\mathrm{C} \equiv \mathrm{C}-\mathrm{Ph}\right](\mathbf{3 b})$ & 1979 & 1893 & $2101^{\mathrm{b}}$ \\
\hline$\left[\mathrm{Tp}(\mathrm{CO})_{2} \mathrm{~W} \equiv \mathrm{C}-\mathrm{C} \equiv \mathrm{C}-\mathrm{Ph}\right](\mathbf{4 b})$ & 1988 & 1904 & 2102 \\
\hline$\left[\mathrm{Cp}(\mathrm{CO})_{2} \mathrm{~W} \equiv \mathrm{C}-\mathrm{C} \equiv \mathrm{C}-\mathrm{Ph}\right](\mathbf{5 b})$ & 1992 & 1920 & 2105 \\
\hline$\left[(\mathrm{bdmpza})(\mathrm{CO})_{2} \mathrm{~W} \equiv \mathrm{C}-\mathrm{C} \equiv \mathrm{C}-\mathrm{Ph}\right](\mathbf{6 b})$ & 1992 & 1910 & $2097^{\mathrm{b}}$ \\
\hline$\left[\mathrm{Cl}(\right.$ tmeda $\left.)(\mathrm{CO})_{2} \mathrm{~W} \equiv \mathrm{C}-\mathrm{C} \equiv \mathrm{C}-\mathrm{Ph}\right](\mathbf{7 b})$ & 1993 & 1909 & \\
\hline
\end{tabular}

\footnotetext{
a In $\mathrm{CH}_{2} \mathrm{Cl}_{2}$
}

${ }^{\mathrm{b}} \mathrm{In} \mathrm{KBr}$.
From the IR data it also follows that bdmpza is stronger electron-donating than $\mathrm{Cp}$. This result contradicts data published earlier by Burzlaff et al. [22]. Based mainly on the shorter $\mathrm{M}-\mathrm{CO}$ distances in $\left[\mathrm{Tp}^{\prime} \mathrm{M}(\mathrm{CO})_{3}\right]$ and $\left[\mathrm{CpM}(\mathrm{CO})_{3}\right]$ than in $\left[(\right.$ bdmpza $\left.) \mathrm{M}(\mathrm{CO})_{3}\right](\mathrm{M}=\mathrm{Mn}$, $\mathrm{Re})$ they concluded that bdmpza would be less electrondonating than $\mathrm{Cp}$ and $\mathrm{Tp}^{\prime}$. However, a change in donor capacity of $\mathrm{Tp}^{\prime}, \mathrm{Tp}$ and $\mathrm{Cp}$ in compounds of transition metals belonging to different groups has been recognized before [23]. Apparently this dependence of the electron-donor ability on the metal also holds true for bdmpza.

The carbonyl and the carbyne resonances in the ${ }^{13} \mathrm{C}$-NMR spectra are rather insensitive to changes in the tripodal ligand ( $\mathrm{Tp}^{\prime}$, Tp and bdmpza) and appear at $\delta=226.6 \pm 0.7$ and $\delta=250.4 \pm 3.1 \mathrm{ppm}$ (Table 2). The same applies to both alkynyl carbon atoms. Surprisingly, substitution of carboxylate for the trans-pyrazolyl group does not significantly affect the $\mathrm{W} \equiv C$ resonance. In contrast, in the trans-chloro complexes 7a,b all carbon resonances $(C \mathrm{O}, \mathrm{W} \equiv C-C \equiv C)$ are shifted towards higher field, the resonance of the carbyne carbon even by ca. 20 ppm.

When the pyrazole-containing tripodal ligands are replaced by cyclopentadienide a significant shift towards higher field for the carbonyl resonance and, conversely, towards lower field for the carbyne resonance is observed.

Thus, several metal-ligand fragments are now available for modifying the properties of the alkynylcarbyne ligand. Furthermore, due to the $\mathrm{C}=\mathrm{O}$ functionality, a fine-tuning of the electronic properties of the new bdmpza group should be possible through addition of Lewis acids. These new alkynylcarbyne complexes should constitute good starting compounds for chain extensions and for the synthesis of binuclear complexes with an odd number of bridging carbon atoms. The high thermal stability of the complexes $\mathbf{3} \mathbf{a}, \mathbf{b}-\mathbf{7} \mathbf{a}, \mathbf{b}$ should make coupling reactions feasible which usually require elevated temperatures. Preliminary results already indicate that $7 \mathrm{a}$ can be desilyated by e.g. $\left[\mathrm{NBu}_{4}\right] \mathrm{F}-\mathrm{THF}$ (Table $3)$.

\section{Experimental}

\subsection{General}

All operations were carried out under either nitrogen or Ar by using conventional Schlenk techniques. Solvents were dried by refluxing over sodium-benzophenone ketyl or $\mathrm{CaH}_{2}$ and were freshly distilled prior to use. The silica gel used for chromatography (J.T. Baker, silica gel for flash chromatography) was saturated with Ar. The yields refer to analytically pure compounds and were not optimized. NaTp [6] and 
Table 3

Selected ${ }^{13} \mathrm{C}-\mathrm{NMR}$ resonances (in ppm) of complexes $\mathbf{3} \mathbf{a}, \mathbf{b}-\mathbf{7} \mathbf{a}, \mathbf{b}$

\begin{tabular}{|c|c|c|c|c|}
\hline Complex & $\delta(\mathrm{CO})$ & $\delta(\mathrm{W} \equiv \mathrm{C})$ & $\delta\left(\mathrm{C}_{\alpha}\right)$ & $\delta\left(\mathrm{C}_{\beta}\right)$ \\
\hline $\begin{array}{l}{\left[\mathrm{Tp}^{\prime}(\mathrm{CO})_{2} \mathrm{~W} \equiv \mathrm{C}-\mathrm{C} \equiv \mathrm{C}-\mathrm{SiMe}_{3}\right]} \\
\quad(3 \mathrm{a})^{\mathrm{a}}{ }^{\mathrm{a}}\end{array}$ & 226.1 & 247.3 & 120.4 & 79.5 \\
\hline $\begin{array}{l}{\left[\mathrm{Tp}(\mathrm{CO})_{2} \mathrm{~W} \equiv \mathrm{C}-\mathrm{C} \equiv \mathrm{C}-\mathrm{SiMe}_{3}\right]} \\
\quad(\mathbf{4 a})^{\mathrm{b}}{ }^{b}\end{array}$ & 226.5 & 253.4 & 120.9 & 80.7 \\
\hline $\begin{array}{l}{\left[\mathrm{Cp}(\mathrm{CO})_{2} \mathrm{~W} \equiv \mathrm{C}-\mathrm{C} \equiv \mathrm{C}-\mathrm{SiMe}_{3}\right]} \\
\quad(\mathbf{5 a})^{\mathrm{b}}\end{array}$ & 222.2 & 266.3 & 123.0 & 86.1 \\
\hline $\begin{array}{l}{\left[(\mathrm{bdmpza})(\mathrm{CO})_{2}-\mathrm{W} \equiv \mathrm{C}-\right.} \\
\left.\mathrm{C} \equiv \mathrm{C}-\mathrm{SiMe}_{3}\right](\mathbf{6 a})^{\mathrm{b}}\end{array}$ & 225.9 & 244.1 & 121.1 & 78.8 \\
\hline $\begin{array}{c}{\left[\mathrm{Cl}(\mathrm{tmeda})(\mathrm{CO})_{2}-\mathrm{W} \equiv \mathrm{C}-\right.} \\
\left.\mathrm{C} \equiv \mathrm{C}-\mathrm{SiMe}_{3}\right](7 \mathrm{a})^{\mathrm{a}}\end{array}$ & 222.0 & 232.4 & 118.8 & 68.2 \\
\hline $\begin{array}{l}{\left[\mathrm{Tp}^{\prime}(\mathrm{CO})_{2} \mathrm{~W} \equiv \mathrm{C}-\mathrm{C} \equiv \mathrm{C}-\mathrm{Ph}\right]} \\
\quad(\mathbf{3 b})^{\mathrm{b}}\end{array}$ & 227.3 & 247.3 & 122.5 & 71.4 \\
\hline $\begin{array}{l}{\left[\mathrm{Tp}(\mathrm{CO})_{2} \mathrm{~W} \equiv \mathrm{C}-\mathrm{C} \equiv \mathrm{C}-\mathrm{Ph}\right]} \\
\quad(\mathbf{4 b})^{\mathrm{b}}\end{array}$ & 226.7 & 251.4 & 122.3 & 72.1 \\
\hline $\begin{array}{l}{\left[\mathrm{Cp}(\mathrm{CO})_{2} \mathrm{~W} \equiv \mathrm{C}-\mathrm{C} \equiv \mathrm{C}-\mathrm{Ph}\right]} \\
\quad(\mathbf{5 b})^{\mathrm{b}}\end{array}$ & 222.4 & 264.2 & 122.3 & 76.7 \\
\hline $\begin{array}{l}{\left[(\mathrm{bdmpza})(\mathrm{CO})_{2}-\mathrm{W} \equiv \mathrm{C}-\right.} \\
\quad \mathrm{C} \equiv \mathrm{C}-\mathrm{Ph}](\mathbf{6 b})^{\mathrm{b}}\end{array}$ & 226.0 & 248.9 & 122.3 & 69.8 \\
\hline $\begin{array}{l}{\left[\mathrm{Cl}(\mathrm{tmeda})(\mathrm{CO})_{2}-\mathrm{W} \equiv \mathrm{C}-\right.} \\
\quad \mathrm{C} \equiv \mathrm{C}-\mathrm{Ph}](\mathbf{7 b})^{\mathrm{a}}\end{array}$ & 222.4 & 230.4 & 105.2 & 68.2 \\
\hline
\end{tabular}

${ }^{\mathrm{a}}$ In $\mathrm{CDCl}_{3}$.

${ }^{\mathrm{b}}$ In $d_{6}$-acetone.

$\mathrm{KTp}^{\prime}[24]$ were prepared according to literature procedures. K[bdmpza] [8] was supplied by $\operatorname{Dr}$ N. Burzlaff. Trimethylsilylacetylene (Fluka), phenylacetylene (Merck), $n$-BuLi (Chemetall), $\left[\mathrm{W}(\mathrm{CO})_{6}\right]$ and trifluoracetic anhydride (Aldrich) were commercial products and were used without further purification. IR: BioRad FT-IR spectrophotometer. ${ }^{1} \mathrm{H}-\mathrm{NMR},{ }^{13} \mathrm{C}-\mathrm{NMR}$ : Bruker AC 250, Bruker DRX 600. Unless specifically mentioned, ${ }^{1} \mathrm{H}-\mathrm{NMR}$ spectra were recorded at 250 $\mathrm{MHz}$ and ${ }^{13} \mathrm{C}-\mathrm{NMR}$ at $151 \mathrm{MHz}$ at room temperature (r.t.). Chemical shifts are reported relative to the residual solvent peaks $\left[\mathrm{CD}_{3} \mathrm{COCD}_{3}: \delta=2.04\left({ }^{1} \mathrm{H}\right)\right.$ and 29.8 ppm $\left({ }^{13} \mathrm{C}\right), \mathrm{CDCl}_{3}: \delta=7.24\left({ }^{1} \mathrm{H}\right)$ and $\left.77.0 \mathrm{ppm}\left({ }^{13} \mathrm{C}\right)\right]$. MS: Finnigan MAT 312 (EI) or Finnigan MAT 312/ AMD5000 (FAB).

\subsection{General procedure for the synthesis of the complexes 3-6}

At $-30{ }^{\circ} \mathrm{C}, 5.0 \mathrm{mmol}$ of trimethylsilylacetylene and phenylacetylene, respectively, in $30 \mathrm{ml}$ of THF was lithiated with a $15 \%$ solution of $n$-BuLi in hexane. After $0.5 \mathrm{~h}, 5.0 \mathrm{mmol}$ of $\left[\mathrm{W}(\mathrm{CO})_{6}\right]$ was added to the solution. The resulting red solution was stirred at r.t. for $1 \mathrm{~h}$ and then cooled to $-80{ }^{\circ} \mathrm{C}$. $\left(\mathrm{CF}_{3} \mathrm{CO}\right)_{2} \mathrm{O}(5.0$ $\mathrm{mmol}$ ) of was added. $\mathrm{CO}$ evolution was observed. The solution was warmed to $-50{ }^{\circ} \mathrm{C}$ and $5.0 \mathrm{mmol}$ of $\mathrm{NaTp}, \mathrm{KTp}$ and $\mathrm{NaCp}$, respectively, was added. When the $\mathrm{CO}$ evolution stopped after warming to r.t. the solvent was removed in vacuo. The dark brown residue was dissolved in THF and chromatographed at $-20{ }^{\circ} \mathrm{C}$ on silica gel.

\subsubsection{Dicarbonyl[hydro(tris-3,5-dimethylpyrazol- \\ 1-yl)borato](trimethylsilylpropynylidyne)-tungsten (3a)}

Chromatography with pentane afforded a purple band. Removal of the solvent from the purple fraction yielded complex $3 a$ as a red-purple microcrystalline powder. Yield: $900 \mathrm{mg}\left(28 \%\right.$ relative to $\left.\left[\mathrm{W}(\mathrm{CO})_{6}\right]\right)$. Dec. $>208{ }^{\circ} \mathrm{C}$. IR $\left(\mathrm{THF}, \mathrm{cm}^{-1}\right) v(\mathrm{C} \equiv \mathrm{C}) 2052 \mathrm{w}, v(\mathrm{CO})$ $1982 \mathrm{~s}, 1896$ s. ${ }^{1} \mathrm{H}-\mathrm{NMR}\left(\mathrm{CDCl}_{3}\right): \delta=0.15$ (s, 9H, $\left.\mathrm{Si}\left(\mathrm{CH}_{3}\right)_{3}\right), 2.28$ (s, 3H, pz-C $\left.{ }_{3} \mathrm{Me}\right), 2.33$ (s, 9H, pz$\left.\mathrm{C}_{5} \mathrm{Me}\right), 2.55\left(\mathrm{~s}, 6 \mathrm{H}, \mathrm{pz}-\mathrm{C}_{3} \mathrm{Me}\right), 5.71\left(\mathrm{~s}, 1 \mathrm{H}, \mathrm{pz}-\mathrm{C}_{4} \mathrm{H}\right)$, $5.88\left(\mathrm{~s}, 2 \mathrm{H}, \mathrm{pz}-\mathrm{C}_{4} \mathrm{H}\right) .{ }^{13} \mathrm{C}-\mathrm{NMR}\left(\mathrm{CDCl}_{3}\right): \delta=-0.5$ $\left(\mathrm{Si}\left(\mathrm{CH}_{3}\right)_{3}\right), 12.6\left(\mathrm{pz}-\mathrm{C}_{5} \mathrm{Me}\right), 15.1\left(\mathrm{pz}-\mathrm{C}_{3} \mathrm{Me}\right), 16.4$ (pz$\left.\mathrm{C}_{3} \mathrm{Me}\right), 79.5\left(\mathrm{C}_{\beta}\right), 106.4\left(\mathrm{pz}_{-} \mathrm{C}_{4}\right), 120.4\left(\mathrm{C}_{\alpha}\right), 144.4$ (pz$\left.\mathrm{C}_{3}\right), 145.2\left(\mathrm{pz}-\mathrm{C}_{3}\right), 151.8\left(\mathrm{pz}-\mathrm{C}_{5}\right), 152.2\left(\mathrm{pz} \mathrm{C}_{5}\right), 226.1(\mathrm{t}$, $J(\mathrm{WC})=162 \mathrm{~Hz}, \mathrm{CO}), 247.3 \quad(\mathrm{t}, J(\mathrm{WC})=198 \mathrm{~Hz}$, $\mathrm{W} \equiv \mathrm{C})$. FABMS (NBA); $m / z(\%): 646(4)\left[\mathrm{M}^{+}\right], 618(10)$ [M+ $-\mathrm{CO}], 590(9)\left[\mathrm{M}^{+}-2 \mathrm{CO}\right], 73$ (100) [ $\left.\mathrm{Si}\left(\mathrm{CH}_{3}\right)_{3}\right]$. Anal. Found: C, 42.89; H, 4.90; N, 12.65. Calc. for $\mathrm{C}_{23} \mathrm{H}_{31} \mathrm{BN}_{6} \mathrm{O}_{2} \mathrm{SiW}$ (646.3): C, 42.74; $\mathrm{H}, 4.83 ; \mathrm{N}$, $13.00 \%$.

\subsubsection{Dicarbonyl[hydro(tris-3,5-dimethylpyrazol- 1-yl)borato](phenylpropynylidyne)tungsten (3b)}

Chromatography with pentane- $-\mathrm{CH}_{2} \mathrm{Cl}_{2}$ (4:1) gave a purple band. Removal of the solvent from the purple fraction afforded complex $\mathbf{3 b}$ as a red-purple microcrystalline powder. Yield: $520 \mathrm{mg}(14 \%$ relative to $\left.\left[\mathrm{W}(\mathrm{CO})_{6}\right]\right)$. Dec. $>182{ }^{\circ} \mathrm{C}$. IR (THF, $\left.\mathrm{cm}^{-1}\right) v(\mathrm{CO})$ 1979 s, 1893 s. ${ }^{1} \mathrm{H}-\mathrm{NMR}\left(\mathrm{CDCl}_{3}\right): \delta=2.30(\mathrm{~s}, 3 \mathrm{H}$, pz-C $\left.{ }_{5} \mathrm{Me}\right), 2.35$ (s, 3H, pz-C $\left.{ }_{3} \mathrm{Me}\right), 2.36$ (s, 6H, pz$\left.\mathrm{C}_{5} \mathrm{Me}\right), 2.59$ (s, 6H, pz- $\left.\mathrm{C}_{3} \mathrm{Me}\right), 5.73\left(\mathrm{~s}, 1 \mathrm{H}, \mathrm{pz}-\mathrm{C}_{4} \mathrm{H}\right)$, $5.89\left(\mathrm{~s}, 2 \mathrm{H}, \mathrm{pz}-\mathrm{C}_{4} \mathrm{H}\right), 7.15-7.50\left(\mathrm{~m}, 5 \mathrm{H}, \mathrm{C}_{6} \mathrm{H}_{5}\right) .{ }^{13} \mathrm{C}-$ NMR: $\delta=12.6\left(\mathrm{~s}, \mathrm{pz}-\mathrm{C}_{5} \mathrm{Me}\right), 12.6\left(\mathrm{~s}, \mathrm{pz}-\mathrm{C}_{5} \mathrm{Me}\right), 15.3$ (s, pz- $\left.\mathrm{C}_{3} \mathrm{Me}\right), 16.5$ (s, pz- $\left.\mathrm{C}_{3} \mathrm{Me}\right), 71.4\left(\mathrm{C}_{\beta}\right), 106.6\left(\mathrm{C}_{1}, \mathrm{Ph}\right)$, $107.5\left(\mathrm{~s}, \mathrm{pz}-\mathrm{C}_{4}\right), 107.7\left(\mathrm{~s}, \mathrm{pz}-\mathrm{C}_{4}\right), 122.5\left(\mathrm{C}_{\alpha}\right), 129.7(\mathrm{Ph})$, $129.9(\mathrm{Ph}), 133.2(\mathrm{Ph}), 146.0\left(\mathrm{~s}, \mathrm{pz}-\mathrm{C}_{3}\right), 146.9\left(\mathrm{~s}, \mathrm{pz}-\mathrm{C}_{3}\right)$, $152.7\left(\mathrm{~s}, \mathrm{pz}-\mathrm{C}_{5}\right), 152.9\left(\mathrm{~s}, \mathrm{pz}-\mathrm{C}_{5}\right), 227.3(\mathrm{t}, J(\mathrm{WC})=160$ $\mathrm{Hz}, \mathrm{CO}), 247.3(\mathrm{~W} \equiv \mathrm{C})$. FABMS (NBA); $m / z(\%): 650$ (8) $\left[\mathrm{M}^{+}\right], 622(10)\left[\mathrm{M}^{+}-\mathrm{CO}\right], 594(10)\left[\mathrm{M}^{+}-2 \mathrm{CO}\right]$. Anal. Found: C, 48.00; H, 4.18; N, 12.75. Calc. for $\mathrm{C}_{26} \mathrm{H}_{27} \mathrm{BN}_{6} \mathrm{O}_{2} \mathrm{~W}$ (650.2): C, 48.03; H, 4.19; N, 12.93\%.

\subsubsection{Dicarbonyl[hydro(trispyrazol-1-yl)borato](tri- methylsilylpropynylidyne)tungsten (4a)}

Chromatography with pentane $-\mathrm{CH}_{2} \mathrm{Cl}_{2}$ (9:1) gave a red band. Removal of the solvent from the red fraction afforded complex $4 \mathbf{a}$ as a red microcrystalline powder. Yield: $870 \mathrm{mg}\left(31 \%\right.$ relative to $\left.\left[\mathrm{W}(\mathrm{CO})_{6}\right]\right)$. Dec. > $164{ }^{\circ} \mathrm{C}$. IR (THF, $\left.\mathrm{cm}^{-1}\right) v(\mathrm{C} \equiv \mathrm{C}) 2056 \mathrm{w}, v(\mathrm{CO}) 1991$ s, 1906 s. ${ }^{1} \mathrm{H}-\mathrm{NMR}\left(\mathrm{CDCl}_{3}\right): \delta=0.18\left(\mathrm{~s}, 9 \mathrm{H}, \mathrm{Si}\left(\mathrm{CH}_{3}\right)_{3}\right)$, $6.13\left(\mathrm{t}, J^{3}=2.1 \mathrm{~Hz}, 1 \mathrm{H}, \mathrm{pz}-\mathrm{C}_{4} \mathrm{H}\right), 6.24\left(\mathrm{t}, J^{3}=2.2 \mathrm{~Hz}\right.$, $\left.2 \mathrm{H}, \quad \mathrm{pz}-\mathrm{C}_{4} \mathrm{H}\right), 7.58\left(\mathrm{~d}, 1 \mathrm{H}, \mathrm{pz}-\mathrm{C}_{5} \mathrm{H}\right), 7.60(\mathrm{~d}, 1 \mathrm{H}$, pz- $\left.\mathrm{C}_{3} \mathrm{H}\right), 7.64\left(\mathrm{~d}, J^{3}=2.2 \mathrm{~Hz}, 2 \mathrm{H}, \mathrm{pz}-\mathrm{C}_{5} \mathrm{H}\right), 8.01(\mathrm{~d}$, 
$J^{3}=1.9 \quad \mathrm{~Hz}, \quad 2 \mathrm{H}, \quad$ pz-C $\left.{ }_{3} \mathrm{H}\right) . \quad{ }^{13} \mathrm{C}-\mathrm{NMR}: \quad \delta=-0.4$ $\left(\mathrm{Si}\left(\mathrm{CH}_{3}\right)_{3}\right), 80.7\left(\mathrm{t}, J^{3}=4 \mathrm{~Hz}, \mathrm{C}_{\beta}\right), 107.2\left(\mathrm{pz}^{-\mathrm{C}_{4}}\right), 120.9$ $\left(\mathrm{t}, J^{2}=28 \mathrm{~Hz}, \mathrm{C}_{\alpha}\right), 137.1\left(\mathrm{pz}-\mathrm{C}_{3}\right), 145.2\left(\mathrm{pz}^{-\mathrm{C}_{5}}\right), 146.2$ $\left(\mathrm{pz}-\mathrm{C}_{5}\right), 226.5(\mathrm{t}, J(\mathrm{WC})=164 \mathrm{~Hz}, \mathrm{CO}), 253.4(\mathrm{t}$, $J(\mathrm{WC})=200 \mathrm{~Hz}, \mathrm{~W} \equiv \mathrm{C})$. FABMS (NBA); $m / z(\%): 562$ (38) $\left[\mathrm{M}^{+}\right], 534(24)\left[\mathrm{M}^{+}-\mathrm{CO}\right], 73(68)\left[\mathrm{Si}\left(\mathrm{CH}_{3}\right)_{3}\right], 68$ (43) $\left[\mathrm{C}_{3} \mathrm{H}_{4} \mathrm{~N}_{2}\right]$. Anal. Found: $\mathrm{C}, 37.19 ; \mathrm{H}, 3.89 ; \mathrm{N}$, 14.59. Calc. for $\mathrm{C}_{17} \mathrm{H}_{19} \mathrm{BN}_{6} \mathrm{O}_{2} \mathrm{SiW}$ (562.1): C, 36.32; $\mathrm{H}$, $3.41 ; \mathrm{N}, 14.95 \%$.

\subsubsection{Dicarbonyl[hydro(trispyrazol-1-yl)borato](phenyl- propynylidyne)tungsten (4b)}

Chromatography with pentane $-\mathrm{CH}_{2} \mathrm{Cl}_{2}$ (4:1) gave a red band. Removal of the solvent from the red fraction afforded complex $\mathbf{4} \mathbf{b}$ as a red microcrystalline powder. Yield: $780 \mathrm{mg}\left(28 \%\right.$ relative to $\left.\left[\mathrm{W}(\mathrm{CO})_{6}\right]\right)$. Dec. > $135^{\circ} \mathrm{C}$. IR (THF, $\left.\mathrm{cm}^{-1}\right) v(\mathrm{C} \equiv \mathrm{C}) 2102 \mathrm{vw}, v(\mathrm{CO}) 1988$ s, 1904 s. ${ }^{1} \mathrm{H}-\mathrm{NMR}: \delta=6.30\left(\mathrm{t}, J^{3}=2.1 \mathrm{~Hz}, 1 \mathrm{H}\right.$, pz- $\left.\mathrm{C}_{4} \mathrm{H}\right), 6.40\left(\mathrm{t}, J^{3}=2.3 \mathrm{~Hz}, 2 \mathrm{H}, \mathrm{pz}-\mathrm{C}_{4} \mathrm{H}\right), 7.20-7.60$ $(\mathrm{m}, 5 \mathrm{H}, \mathrm{Ph}), 7.83\left(\mathrm{~d}, J^{3}=2.0 \mathrm{~Hz}, 1 \mathrm{H}, \mathrm{pz}_{-} \mathrm{C}_{5} \mathrm{H}\right), 7.90(\mathrm{~d}$, $\left.J^{3}=2.2 \mathrm{~Hz}, 1 \mathrm{H}, \mathrm{pz}-\mathrm{C}_{3} \mathrm{H}\right), 7.96\left(\mathrm{~d}, J^{3}=2.3 \mathrm{~Hz}, 2 \mathrm{H}\right.$, pz- $\left.\mathrm{C}_{5} \mathrm{H}\right), 8.11\left(\mathrm{~d}, J^{3}=1.9 \mathrm{~Hz}, 2 \mathrm{H}, \mathrm{pz}-\mathrm{C}_{3} \mathrm{H}\right) .{ }^{13} \mathrm{C}-\mathrm{NMR}$ : $\delta=72.1\left(\mathrm{C}_{\beta}\right), 107.2\left(\mathrm{pz}-\mathrm{C}_{4}\right), 107.4\left(\mathrm{C}_{1}, \mathrm{Ph}\right), 122.3\left(\mathrm{C}_{\alpha}\right)$, $129.7(\mathrm{Ph}), 130.0(\mathrm{Ph}), 133.2(\mathrm{Ph}), 137.1\left(\mathrm{pz}-\mathrm{C}_{3}\right), 137.3$ $\left(\mathrm{pz}-\mathrm{C}_{3}\right), 145.0\left(\mathrm{pz}-\mathrm{C}_{5}\right), 146.2\left(\mathrm{pz}-\mathrm{C}_{5}\right), 226.7(\mathrm{t}, J(\mathrm{WC})=$ $64 \mathrm{~Hz}, \mathrm{CO}), 251.4(\mathrm{~W} \equiv \mathrm{C})$. EIMS; $m / z(\%): 566(5)$ $\left[\mathrm{M}^{+}\right], 538(6)\left[\mathrm{M}^{+}-\mathrm{CO}\right], 512(4)\left[\mathrm{M}^{+}-2 \mathrm{CO}\right]$. Anal. Found: C, 43.66; H, 3.23; N, 14.12. Calc. for $\mathrm{C}_{20} \mathrm{H}_{15} \mathrm{BN}_{6} \mathrm{O}_{2} \mathrm{~W}$ (566.0): C, 42.44; H, 2.67; N, 14.85\%.

\subsubsection{Dicarbonyl(cyclopentadienyl)(trimethylsilyl- propynylidyne)tungsten (5a)}

Chromatography with pentane- $-\mathrm{CH}_{2} \mathrm{Cl}_{2}(4: 1)$ gave a red band. Removal of the solvent from the red fraction afforded complex 5 a as a red microcrystalline powder. Yield: $1160 \mathrm{mg}\left(56 \%\right.$ relative to $\left.\left[\mathrm{W}(\mathrm{CO})_{6}\right]\right)$. Dec. > $115{ }^{\circ} \mathrm{C}$. IR (THF, $\left.\mathrm{cm}^{-1}\right) v(\mathrm{C} \equiv \mathrm{C}) 2057 \mathrm{w}, v(\mathrm{CO}) 1995$ s, 1923 s. ${ }^{1} \mathrm{H}-\mathrm{NMR}: \delta=0.15\left(\mathrm{~s}, 9 \mathrm{H}, \mathrm{Si}\left(\mathrm{CH}_{3}\right)_{3}\right), 5.87(\mathrm{~s}$, $\left.5 \mathrm{H}, \mathrm{C}_{5} \mathrm{H}_{5}\right) \cdot{ }^{13} \mathrm{C}-\mathrm{NMR}: \delta=-0.8\left(\mathrm{Si}\left(\mathrm{CH}_{3}\right)_{3}\right), 86.1\left(\mathrm{C}_{\beta}\right)$, $93.6\left(\mathrm{C}_{5} \mathrm{H}_{5}\right), 123.0\left(\mathrm{C}_{\alpha}\right), 222.2(\mathrm{CO}), 266.3(\mathrm{~W} \equiv \mathrm{C})$. FABMS (NBA); $m / z(\%): 414(11)\left[\mathrm{M}^{+}\right], 386(5)\left[\mathrm{M}^{+}\right.$ $-\mathrm{CO}], 358$ (12) $\left[\mathrm{M}^{+}-2 \mathrm{CO}\right], 73$ (100) $\left[\mathrm{Si}\left(\mathrm{CH}_{3}\right)_{3}\right]$. Anal. Found: C, 38.05; H, 3.59. Calc. for $\mathrm{C}_{13} \mathrm{H}_{14} \mathrm{O}_{2} \mathrm{SiW}$ (414.2): C, 37.70; H, 3.41\%.

\subsubsection{Dicarbonyl(cyclopentadienyl)- \\ (phenylpropynylidyne)tungsten (5b)}

Chromatography with pentane- $-\mathrm{CH}_{2} \mathrm{Cl}_{2}(4: 1)$ gave a red band. Removal of the solvent from the red fraction afforded complex $\mathbf{5 b}$ as a red microcrystalline powder. Yield: $794 \mathrm{mg}\left(38 \%\right.$ relative to $\left.\left[\mathrm{W}(\mathrm{CO})_{6}\right]\right)$. Dec. > $136{ }^{\circ} \mathrm{C}$. IR (THF, $\left.\mathrm{cm}^{-1}\right) v(\mathrm{C} \equiv \mathrm{C}) 2105 \mathrm{w}, v(\mathrm{CO}) 1992$ s, 1920 s. ${ }^{1} \mathrm{H}-\mathrm{NMR}: \delta=5.89\left(\mathrm{~s}, 5 \mathrm{H}, \mathrm{C}_{5} \mathrm{H}_{5}\right), 7.3-7.5(\mathrm{~m}$, 5H, $\left.\mathrm{C}_{6} \mathrm{H}_{5}\right) \cdot{ }^{13} \mathrm{C}-\mathrm{NMR}: \delta=76.7\left(\mathrm{C}_{\beta}\right), 93.3\left(\mathrm{C}_{5} \mathrm{H}_{5}\right), 109.6$ $\left(\mathrm{C}_{1}, \mathrm{Ph}\right), 122.3\left(\mathrm{C}_{\alpha}\right), 129.6(\mathrm{Ph}), 130.3(\mathrm{Ph}), 132.5(\mathrm{Ph})$, $222.4(\mathrm{t}, J(\mathrm{WC})=194 \mathrm{~Hz}, \mathrm{CO}) ; 264(\mathrm{t}, J(\mathrm{WC})=226$
$\mathrm{Hz}, \mathrm{W} \equiv \mathrm{C}) . \mathrm{EIMS} ; m / z \quad(\%): 418(43)\left[\mathrm{M}^{+}\right], 390$ (3) $\left[\mathrm{M}^{+}-\mathrm{CO}\right], 362(100)\left[\mathrm{M}^{+}-2 \mathrm{CO}\right]$. Anal. Found: $\mathrm{C}$, 45.73; H, 2.71. Calc. for $\mathrm{C}_{16} \mathrm{H}_{10} \mathrm{O}_{2} \mathrm{~W}$ (418.1): C, 45.96; $\mathrm{H}, 2.41 \%$.

\subsection{General procedure for the synthesis of the complexes $\mathbf{6} \boldsymbol{a}$ and $\mathbf{6} \boldsymbol{b}$}

At $-30{ }^{\circ} \mathrm{C}, 5.0 \mathrm{mmol}$ of trimethylsilylacetylene and phenylacetylene, respectively, in $30 \mathrm{ml}$ of $\mathrm{Et}_{2} \mathrm{O}$ was lithiated with a $15 \%$ solution of $n-\mathrm{BuLi}$ in hexane. After $0.5 \mathrm{~h}, 5.0 \mathrm{mmol}$ of $\left[\mathrm{W}(\mathrm{CO})_{6}\right]$ was added to the solution. The resulting red solution was stirred at r.t. for $1 \mathrm{~h}$ and then cooled to $-80{ }^{\circ} \mathrm{C}$. $\left(\mathrm{CF}_{3} \mathrm{CO}\right)_{2} \mathrm{O}(5.0$ $\mathrm{mmol})$ of was added. $\mathrm{CO}$ evolution was observed. The solution was warmed to $-50{ }^{\circ} \mathrm{C}$ and $5.0 \mathrm{mmol}$ of the $\mathrm{K}$ [bdmpza] was added. When the $\mathrm{CO}$ evolution stopped after warming to r.t. ca. $50 \mathrm{ml}$ of pentane was added. A pale red precipitate formed. The precipitate was washed $3 \times$ with $50 \mathrm{ml}$ of pentane each to remove $\left[\mathrm{W}(\mathrm{CO})_{6}\right]$. The powder was dried in vacuo and then recrystallized from THF.

\subsubsection{Bis(3,5-dimethylpyrazol-1-yl)acetato- \\ (dicarbonyl)(trimethylsilylpropynylidyne)tungsten (6a)}

Yield: $2.5 \mathrm{~g}\left(83 \%\right.$ relative to $\left.\left[\mathrm{W}(\mathrm{CO})_{6}\right]\right)$. Dec. $>$ $205{ }^{\circ} \mathrm{C}$. IR (THF, $\left.\mathrm{cm}^{-1}\right) v(\mathrm{C} \equiv \mathrm{C}) 2052 \mathrm{w}, v(\mathrm{CO}) 1995$ s, $1912 \mathrm{~s}, 1693 \mathrm{~m} .{ }^{1} \mathrm{H}-\mathrm{NMR}: \delta=0.14\left(\mathrm{~s}, 9 \mathrm{H}, \mathrm{Si}\left(\mathrm{CH}_{3}\right)_{3}\right)$, 2.59 (s, 6H, pz-CMe), 2.60 (s, 6H, pz-CMe), 6.36 (s, $\left.2 \mathrm{H}, \mathrm{pz}-\mathrm{C}_{4} \mathrm{H}\right), 6.62(\mathrm{~s}, 1 \mathrm{H}, \mathrm{CH}) .{ }^{13} \mathrm{C}-\mathrm{NMR}: \delta=-0.4$ $\left(\mathrm{Si}\left(\mathrm{CH}_{3}\right)_{3}\right), 11.0$ (pz-CMe), 16.1 (pz-CMe), $69.0(\mathrm{CH})$, $78.8\left(\mathrm{C}_{\beta}\right), 108.9\left(\mathrm{pz}-\mathrm{C}_{4}\right), 121.1\left(\mathrm{t}, J^{2}(\mathrm{WC})=27 \mathrm{~Hz} ; \mathrm{C}_{\alpha}\right)$, $144.2\left(\mathrm{pz}_{5} \mathrm{C}_{5}\right), 154.7\left(\mathrm{pz}-\mathrm{C}_{3}\right), 163.7\left(\mathrm{CO}_{2}\right), 225.9(\mathrm{t}$, $J(\mathrm{WC})=172 \mathrm{~Hz}, \mathrm{CO}), 244.1 \quad(\mathrm{t}, J(\mathrm{WC})=196 \mathrm{~Hz}$; $\mathrm{W} \equiv \mathrm{C})$. FABMS (NBA); $m / z(\%): 603(12)\left[\mathrm{M}^{+}+\mathrm{Li}\right]$, $596(14)\left[\mathrm{M}^{+}\right], 496(22)\left[\mathrm{M}^{+}-2 \mathrm{CO}-\mathrm{CO}_{2}\right], 455$ (52) $\left[\mathrm{M}^{+}-2 \mathrm{CO}-\mathrm{CO}_{2}-\mathrm{C}_{2} \mathrm{H}_{3} \mathrm{~N}\right], 108$ (100) $\left[\mathrm{C}_{6} \mathrm{H}_{8} \mathrm{~N}_{2}\right]$. Anal. Found: C, 39.77; H, 4.09; N, 9.16. Calc. for $\mathrm{C}_{20} \mathrm{H}_{24} \mathrm{~N}_{4} \mathrm{O}_{4} \mathrm{SiW}$ (596.4): C, 40.28; H, 4.06; N, 9.39\%.

\subsubsection{Bis(3,5-dimethylpyrazol-1-yl)acetato(dicarbonyl)- (phenylpropynylidyne)tungsten (6b)}

Yield: $2.7 \mathrm{~g}\left(91 \%\right.$ relative to $\left.\left[\mathrm{W}(\mathrm{CO})_{6}\right]\right)$. Dec. > $206{ }^{\circ} \mathrm{C}$. IR $\left(\mathrm{KBr}, \mathrm{cm}^{-1}\right) v(\mathrm{C} \equiv \mathrm{C}) 2097$; (THF, $\mathrm{cm}^{-1}$ ) $v(\mathrm{CO}) 1992 \mathrm{~s}, 1910 \mathrm{~s}, 1692 \mathrm{~m} .{ }^{1} \mathrm{H}-\mathrm{NMR}: \delta=2.61$ (s, $6 \mathrm{H}, \mathrm{Me}), 2.64$ (s, 6H, Me), 6.37 (s, 2H, $\left.\mathrm{C}_{4} \mathrm{H}\right), 6.63$ (s, $1 \mathrm{H}, \mathrm{CH}), 7.3-7.5\left(\mathrm{~m}, 5 \mathrm{H}, \mathrm{C}_{6} \mathrm{H}_{5}\right),{ }^{13} \mathrm{C}-\mathrm{NMR}: \delta=11.0$ $\left(\mathrm{C}_{5} \mathrm{Me}\right), 16.2\left(\mathrm{C}_{3} \mathrm{Me}\right), 69.1(\mathrm{CH}), 69.8\left(\mathrm{C}_{\beta}\right), 107.4\left(\mathrm{C}_{1}\right.$, $\mathrm{Ph}), 108.9\left(\mathrm{pz}-\mathrm{C}_{4}\right), 122.3\left(\mathrm{C}_{\alpha}\right), 129.6(\mathrm{Ph}), 129.9(\mathrm{Ph})$, $133.2(\mathrm{Ph}), 144.2(\mathrm{pz}-\mathrm{C}), 154.7$ (pz-C), $163.6\left(\mathrm{CO}_{2}\right)$, 226.0 (CO), 248.9 (WझC). FABMS (NBA); $m / z(\%)$ : $600(4)\left[\mathrm{M}^{+}\right], 500(2)\left[\mathrm{M}^{+}-2 \mathrm{CO}-\mathrm{CO}_{2}\right], 459$ (4) $\left[\mathrm{M}^{+}\right.$ $-2 \mathrm{CO}-\mathrm{CO}_{2}-\mathrm{C}_{2} \mathrm{H}_{3} \mathrm{~N}$ ]. Anal. Found: $\mathrm{C}, 46.18 ; \mathrm{H}$, 3.46; N, 9.33. Calc. for $\mathrm{C}_{23} \mathrm{H}_{20} \mathrm{~N}_{4} \mathrm{O}_{4} \mathrm{~W}$ (600.3): C, 46.02; $\mathrm{H}, 3.36$; N, $9.33 \%$. 


\subsection{Dicarbonyl(chloro)(trimethylsilylpropynylidyne)- (tetramethylethylendiamine)tungsten (7a)}

At $-80{ }^{\circ} \mathrm{C}, 5.0 \mathrm{mmol}$ of $1.6 \mathrm{M}$ solution of $n$-BuLi in hexane were added dropwise to a solution of $5.0 \mathrm{mmol}$ of trimethylsilylacetylene in $30 \mathrm{ml}$ of THF. The solution was stirred for $10 \mathrm{~min}$ and then gradually warmed to r.t. A suspension of $5.0 \mathrm{mmol}$ of $\left[\mathrm{W}(\mathrm{CO})_{6}\right]$ in $50 \mathrm{ml}$ of THF cooled to $-5{ }^{\circ} \mathrm{C}$ was added. The solution immediately turned orange. It was cooled to $-80{ }^{\circ} \mathrm{C}$ and a solution of $5.0 \mathrm{mmol}$ of $\mathrm{C}_{2} \mathrm{O}_{2} \mathrm{Cl}_{2}$ in $20 \mathrm{ml}$ of THF was added dropwise. The color of the solution changed to red-brown and a $\mathrm{CO}$ evolution was observed. The solution was warmed to $-60{ }^{\circ} \mathrm{C}$ and $5.0 \mathrm{mmol}$ of tmeda was added. When the $\mathrm{CO}$ evolution had ceased the solution was heated at $40{ }^{\circ} \mathrm{C}$ for $1 \mathrm{~h}$. The solvent was removed in vacuo. The light brown residue was dissolved in $25 \mathrm{ml}$ of $\mathrm{CH}_{2} \mathrm{Cl}_{2}$ and solution filtered over a $15 \mathrm{~cm}$ layer of silica gel. A red-brown band was eluted which was subsequently chromatographed at $-20{ }^{\circ} \mathrm{C}$ on silica gel. With $\mathrm{CH}_{2} \mathrm{Cl}_{2}$ three fractions were obtained: the first, yellow-brown one contained $\left[\mathrm{W}(\mathrm{CO})_{6}\right]$, the second, yellow-orange one [(CO) $4 \mathrm{~W}(\mathrm{tmeda})]$ and the third, orange fraction finally gave complex yellow-orange $7 a$ as a microcrystalline powder. Yield: $600 \mathrm{mg}$ (24\% relative to $\left.\left[\mathrm{W}(\mathrm{CO})_{6}\right]\right)$. M.p. $>124{ }^{\circ} \mathrm{C}$. IR $\left(\mathrm{CH}_{2} \mathrm{Cl}_{2}, \mathrm{~cm}^{-1}\right) v(\mathrm{C} \equiv \mathrm{C}) 2050 \mathrm{vw}$, br; $v(\mathrm{CO}) 1997 \mathrm{~s}, 1908$ vs. ${ }^{1} \mathrm{H}-\mathrm{NMR}\left(\mathrm{CDCl}_{3}\right): \delta=0.16$ $\left(\mathrm{s}, 9 \mathrm{H}, \mathrm{SiCH}_{3}\right), 2.90\left(\mathrm{~s}, 6 \mathrm{H}, \mathrm{NCH}_{3}\right), 2.91(\mathrm{~s}, 4 \mathrm{H}$, $\left.\mathrm{NCH}_{2}\right), 3.18\left(\mathrm{~s}, 6 \mathrm{H}, \mathrm{NCH}_{3}\right) \cdot{ }^{13} \mathrm{C}-\mathrm{NMR}\left(\mathrm{CDCl}_{3}\right): \delta=$ $-0.0\left(\mathrm{SiCH}_{3}\right), 52.3,58.2,61.2\left(\mathrm{NCH}_{3}, \mathrm{CH}_{2}\right), 68.2\left(\mathrm{C}_{\beta}\right)$, $118.8\left(J^{2}(\mathrm{WC})=28.9 \mathrm{~Hz}, \mathrm{C}_{\alpha}\right), 222.0(J(\mathrm{WC})=173 \mathrm{~Hz}$, $\mathrm{CO}), 232.4(\mathrm{~J}(\mathrm{WC})=210 \mathrm{~Hz}, \mathrm{~W} \equiv \mathrm{C})$. FABMS (NBA); $m / z(\%): 500(18)\left[\mathrm{M}^{+}\right], 472(59)\left[\mathrm{M}^{+}-\mathrm{CO}\right], 465$ (45) $\left[\mathrm{M}^{+}-\mathrm{Cl}\right], 444$ (58) $\left[\mathrm{M}^{+}-2 \mathrm{CO}\right], 409$ (14) $\left[\mathrm{M}^{+}-\right.$ $2 \mathrm{CO}-\mathrm{Cl}$ ], $115(100)$ [tmeda- $\mathrm{H}^{+}$]. Anal. Found: C, 34.44; $\mathrm{H}, 5.34 ; \mathrm{N}, 5.28$. Calc. for $\mathrm{C}_{14} \mathrm{H}_{25} \mathrm{ClN}_{2} \mathrm{O}_{2} \mathrm{SiW}$ (500.8): C, 33.58; H, 5.03; N, 5.59\%.

\subsection{Dicarbonyl(chloro)(phenylpropynylidyne)- (tetramethylethylendiamine)tungsten (7b)}

At $-80{ }^{\circ} \mathrm{C}, 5.0 \mathrm{mmol}$ of phenylacetylene were lithiated in $30 \mathrm{ml}$ of THF by dropwise adding a $15 \%$ solution of $n-\mathrm{BuLi}$ in hexane. After $5 \mathrm{~min}$ of stirring the cooling bath was removed and the solution stirred until r.t. was reached. At $-5{ }^{\circ} \mathrm{C}$, this solution was combined with $5.0 \mathrm{mmol}$ of a solution of $\left[\mathrm{W}(\mathrm{CO})_{6}\right]$ in $50 \mathrm{ml}$ of THF. The resulting red solution was stirred for ca. 20 min while warming to $0{ }^{\circ} \mathrm{C}$ and then cooled to $-80{ }^{\circ} \mathrm{C} .5 .0 \mathrm{mmol}$ of $\mathrm{C}_{2} \mathrm{O}_{2} \mathrm{Cl}_{2}$ was added dropwise. The color of the solution changed to red-brown and a $\mathrm{CO}$ evolution was observed. The solution was warmed to $-60{ }^{\circ} \mathrm{C}$ and $5.0 \mathrm{mmol}$ of tmeda was added. When the $\mathrm{CO}$ evolution had ceased after warming the solution to r.t. and successive heating to $40{ }^{\circ} \mathrm{C}$ for $1 \mathrm{~h}$, the solvent was removed in vacuo. The light brown residue was dissolved in THF and chromatographed at $-20{ }^{\circ} \mathrm{C}$ on silica gel. Chromatography with pentane$\mathrm{CH}_{2} \mathrm{Cl}_{2}$ (1:0) gave a red band. Removal of the solvent from the red fraction afforded complex 9 as a red microcrystalline powder. Yield: $550 \mathrm{mg}$ ( $22 \%$ relative to $\left.\left[\mathrm{W}(\mathrm{CO})_{6}\right]\right) . \quad$ M.p. $>120{ }^{\circ} \mathrm{C}$ (dec.). IR (THF, $\mathrm{cm}^{-1}$ ) $v(\mathrm{CO}) 1993 \mathrm{~s}, 1909$ vs. ${ }^{1} \mathrm{H}-\mathrm{NMR}\left(\mathrm{CDCl}_{3}\right): \delta=2.92(\mathrm{~s}$, $\left.6 \mathrm{H}, \mathrm{CH}_{3}\right), 2.93\left(\mathrm{~s}, 4 \mathrm{H}, \mathrm{CH}_{2}\right), 3.22\left(\mathrm{~s}, 6 \mathrm{H}, \mathrm{CH}_{3}\right), 7.23-$ $7.45\left(\mathrm{~m}, 5 \mathrm{H}, \mathrm{C}_{6} \mathrm{H}_{5}\right) .{ }^{13} \mathrm{C}-\mathrm{NMR}\left(\mathrm{CDCl}_{3}\right): \delta=52.31$, 58.21, $61.21\left(\mathrm{CH}_{3}, \mathrm{CH}_{2}\right), 68.2\left(\mathrm{C}_{\beta}\right), 105.2\left(J^{2}(\mathrm{WC})=30\right.$ $\left.\mathrm{Hz}, \quad \mathrm{C}_{\alpha}\right), \quad 121.8, \quad 128.5, \quad 128.6,132.7(\mathrm{Ph}), 222.4$ $(J(\mathrm{WC})=172 \mathrm{~Hz}, \mathrm{CO}), 230.4(J(\mathrm{WC})=212 \mathrm{~Hz}, \mathrm{~W} \equiv \mathrm{C})$. FABMS (NBA); $m / z$ (\%): 504 (21) $\left[\mathrm{M}^{+}\right], 476$ (59) $\left[\mathrm{M}^{+}-\mathrm{CO}\right], 469(37)\left[\mathrm{M}^{+}-\mathrm{Cl}\right], 448(56)\left[\mathrm{M}^{+}-2 \mathrm{CO}\right]$, 115 (100) [tmeda- $\mathrm{H}^{+}$], 89 (21) [C-Ph]. Anal. Found: C, 39.63; $\mathrm{H}, 4.54 ; \mathrm{N}$, 5.07. Calc. for $\mathrm{C}_{17} \mathrm{H}_{21} \mathrm{ClN}_{2} \mathrm{O}_{2} \mathrm{~W}$ (504.7): C, 40.46; H, 4.19; N, 5.55\%.

\section{6. $X$-ray structural analyses of $\mathbf{6} \boldsymbol{b}$ and $\mathbf{7 b}$}

6b. $\mathrm{C}_{27} \mathrm{H}_{28} \mathrm{~N}_{4} \mathrm{O}_{5} \mathrm{~W}$, molecular mass (672.38), crystal size $0.2 \times 0.2 \times 0.05 \mathrm{~mm}^{3}$ (obtained by recrystallization from THF); crystal system monoclinic, space group $P 2_{1} / c, a=20.617(15) \AA, b=9.680(8) \AA, c=15.743(14)$ $\AA, \beta=111.99(5)^{\circ} ; \quad V=2913.3(41) \AA^{3}, Z=4, D_{\text {calc }}=$ $1.533 \mathrm{~g} \mathrm{~cm}^{-3}$, absorption coefficient $4.005 \mathrm{~mm}^{-1}$, $F(000)$ 1328; scan type: adaptive $\omega, \Theta$ range $2.13-$ $25.0^{\circ}$, scan range $1.6^{\circ}$, scan rate variable $4.0-30.0^{\circ}$ per minute in $\omega ; 5119$ independent reflections, 3478 reflection with $I>2 \sigma(I) ; 334$ refined parameters; $R_{1}=$ $0.0600, w R_{2}=0.1507$. Largest difference peak and hole: +1.818 and $-1.676 \mathrm{e}^{-3}$.

7b. $\mathrm{C}_{18} \mathrm{H}_{23} \mathrm{Cl}_{3} \mathrm{~N}_{2} \mathrm{O}_{2} \mathrm{~W}$, molecular mass (589.58), crystal size $0.3 \times 0.2 \times 0.3 \mathrm{~mm}^{3}$ (obtained by recrystallization from $\mathrm{CH}_{2} \mathrm{Cl}_{2}$ ); crystal system triclinic, space group $P \overline{1}, a=7.704(2) \AA, b=11.921(3) \AA, c=12.961(3) \AA$, $\alpha=101.30(1), \quad \beta=105.21(2), \quad \gamma=105.68(1)^{\circ} ; \quad V=$ 1059.3(5) $\AA^{3}, Z=2, D_{\text {calc }}=1.848 \mathrm{~g} \mathrm{~cm}^{-3}$, absorption coefficient $5.848 \mathrm{~mm}^{-1}, F(000) 572$; scan type: adaptive $\omega, \Theta$ range $2.12-27.05^{\circ}, 4579$ independent reflections, 4344 reflection with $I>2 \sigma(I) ; 220$ refined parameters; $R_{1}=0.0301, w R_{2}=0.0775$. Largest difference peak and hole: +1.220 and $-1.452 \mathrm{e}^{-3}$.

The measurements were performed at $-38(\mathbf{6 b})$ and $-42{ }^{\circ} \mathrm{C}(\mathbf{7 b})$ with a crystal mounted in a glass capillary on a Siemens P4 diffractometer (graphite monochromator, $\mathrm{Mo}-\mathrm{K}_{\alpha}$ radiation, $\lambda=0.71073 \AA$ ). The structures were solved by direct methods using the SHELX-97 program package [25]. The positions of the hydrogen atoms were calculated by assuming ideal geometry and their coordinates were refined together with those of the attached $\mathrm{C}$ atoms as 'riding model'. The positions of all other atoms were refined anisotropically by the full-matrix least-squares method. Complex $\mathbf{6} \mathbf{b}$ crystallized with one equivalent of THF, complex $\mathbf{7 b}$ with one equivalent 
of $\mathrm{CH}_{2} \mathrm{Cl}_{2}$. The solvent molecules were refined anisotropically.

\section{Supplementary material}

Crystallographic data for the structural analysis have been deposited with the Cambridge Crystallographic Data Centre, CCDC nos. 166390 and 166389 for compounds $\mathbf{6 b}$ and $\mathbf{7 b}$, respectively. Copies of this information may be obtained free of charge from The Director, CCDC, 12 Union Road, Cambridge CB2 1EZ, UK (Fax: +44-1223-336033; e-mail: deposit@ccdc. cam.ac.uk or www: http://www.ccdc.cam.ac.uk).

\section{A cknowledgements}

Support of these investigations by the Fonds der Chemischen Industrie is gratefully acknowledged. We also thank Mr B. Weibert for collecting the data sets for the X-ray structural analyses.

\section{R eferences}

[1] J.S. Schumm, D.L. Pearson, J.M. Tour, Angew. Chem. 106 (1996) 1445; Angew. Chem. Int. Ed. Engl. 33 (1996) 1360.

[2] Recent reviews: (a) W. Beck, B. Niemer, M. Wieser, Angew. Chem. 105 (1993) 969; Angew. Chem. Int. Ed. Engl. 32 (1993) 923;

(b) H. Lang, Angew. Chem. 106 (1994) 569; Angew. Chem. Int. Ed. Engl. 33 (1994) 547;

(c) U.H.F. Bunz, Angew. Chem. 108 (1996) 1047; Angew. Chem. Int. Ed. Engl. 35 (1996) 969;

(d) T. Bartik, W. Weng, J.A. Ramsden, S. Szafert, S.B. Falloon, A.M. Arif, J.A. Gladysz, J. Am. Chem. Soc. 120 (1998) 11071 and references cited therein.

[3] T. Bartik, B. Bartik, M. Brady, R. Dembin, J.A. Gladysz, Angew. Chem. 108 (1996) 467; Angew. Chem. Int. Ed. Engl. 35 (1996) 414.
[4] E.O. Fischer, H.J. Kalder, F.H. Köhler, J. Organomet. Chem. 81 (1974) C23.

[5] (a) I.J. Hart, A.F. Hill, F.G.A. Stone, J. Chem. Soc. Dalton Trans. (1989) 2261;

(b) S.J. Dossett, I.J. Hart, F.G.A. Stone, J. Chem. Soc. Dalton Trans. (1990) 3481.

[6] S. Trofimenko, J. Am. Chem. Soc. 89 (1967) 3165.

[7] A. Otero, J. Fernández-Baeza, J. Tejeda, A. Antinolo, F. Carrillo-Hermosilla, E. Diez-Barra, A. Lara-Sánchez, M. Fernández-López, M. Lanfranchi, M.A. Pellinghelli, J. Chem. Soc. Dalton Trans. (1999) 3537.

[8] A. Beck, B. Weibert, N. Burzlaff, Eur. J. Inorg. Chem. (2001) 521.

[9] E.O. Fischer, G. Kreis, C.G. Kreiter, J. Müller, G. Huttner, H. Lorenz, Angew. Chem. 85 (1973) 618; Angew Chem. Int. Ed. Engl. 12 (1973) 564.

[10] E.O. Fischer, H. Hollfelder, P. Friedrich, F.R. Kreiß1, G. Huttner, Angew. Chem. 89 (1977) 416; Angew Chem. Int. Ed. Engl. 16 (1977) 401.

[11] E.O. Fischer, S. Walz, W.R. Wagner, J. Organomet. Chem. 134 (1977) C37.

[12] H. Fischer, E.O. Fischer, J. Organomet. Chem. 69 (1974) C1.

[13] D. Himmelreich, E.O. Fischer, Z. Naturforsch. b 37 (1982) 1218.

[14] A. Mayr, G.A. McDermott, A.M. Dorries, Organometallics 4 (1985) 608.

[15] A. Rahm, W.D. Wulff, A.L. Rheingold, Organometallics 12 (1993) 597.

[16] E.O. Fischer, F.R. Kreissl, J. Organomet. Chem. 35 (1972) C47.

[17] J.-L. Cabioch, S.J. Dossett, I.J. Hart, M.U. Pilotti, F.G.A. Stone, J. Chem. Soc. Dalton Trans. (1991) 519.

[18] R. Dembinski, S. Szafert, P. Haquette, T. Lis, J.A. Gladysz, Organometallics 18 (1999) 5438.

[19] H. Wadepohl, U. Arnold, H. Pritzkow, M.J. Calhorda, L.F. Veiros, J. Organomet. Chem. 587 (1999) 233.

[20] F.H. Allen, O. Kennard, D.G. Watson, L. Brammer, A.G. Orpen, R. Taylor, J. Chem. Soc. Perkin II (1987) S1.

[21] K.E. Torraca, I. Ghiviriga, L. McElwee-White, Organometallics 18 (1999) 2262.

[22] N. Burzlaff, I. Hegelmann, B. Weibert, J. Organomet. Chem. 626 (2001) 16.

[23] D.M. Tellers, S.J. Skoog, R.G. Bergman, Organometallics 19 (2000) 2428.

[24] S. Trofimenko, J. Am. Chem. Soc. 89 (1967) 6288.

[25] G.M. Sheldrick, SHELX-97, Programs for Crystal Structure Analysis, University of Göttingen, Göttingen, Germany, 1997. 